\title{
GEOPOLITICAL VIEW OF UKRAINE: HISTORY OF DEVELOPMENT AND SPECIFICS OF ITS CURRENT TRANSFORMATION
}

\author{
GALINA KOPACHINSKA (1) \\ Faculty of Foreign Relations, Department of Foreign Relations and Regional Studios, Lesia Ukrainka Volyn \\ National University, Lutsk, Ukraine
}

Manuscript received: April 25, 2021

Revised version: June 15, 2021

KopachinsKa G., 2021. Geopolitical view of Ukraine: History of development and specifics of its current transformation. Quaestiones Geographicae 40(4), Bogucki Wydawnictwo Naukowe, Poznań, pp. 47-62. 4 tables.

AвSTRACT: The main task of the research was to investigate and differentiate the historical stages of the formation of Ukraine's geopolitical view, based on the Ukrainian statehood history and works of key researches, which had been directly influenced by the evolution of its geopolitical consciousness and thinking. In the article, three main historical stages of Ukraine's geopolitical view formation were differentiated and the reason why the state's geopolitical view gradually transformed into the state's geopolitical interest after Ukraine attained independence was substantiated. The article includes a SWOT analysis of Ukraine's geopolitical location, based on which the state's geopolitical interests of local, regional and global levels were represented. As Ukraine is in the field of geopolitical orientation of many countries not only in Europe but also around the world, the study of the state's geopolitical view formation and current transformation is topical and can be useful for foreign researchers.

KEYWORDS: Ukraine, historical stages, geopolitical view, geopolitical interest, state's geopolitical location

Corresponding author: Galina Kopachinska, Lesya Ukrainka Volyn National University, Faculty of International Relations,

28 Vynnychenko st. (Building G), Lutsk, Volyn 43005 Ukraine; e-mail: kopachinskaja@gmail.com; kopachinska.galina@vnu.edu.ua

\section{Introduction}

Ukraine's geopolitical view passed a longterm evolution and was strongly influenced by the history of the formation of Ukrainian statehood. As the result of complicated state and legal realities, Ukrainian geopolitical information as well as political and geographical knowledge about it until the early 20th c. were mostly fragmentary in nature and combined together with other country-studies information. Until the beginning of the 20th c., it is impossible to mention the development of geopolitics in the state, but only the formation and development of geopolitical views and geopolitical ideas. At the turn of the 20th c., the first Ukrainian state and political programmes began to appear, which included and substantiated geopolitical principles. During the 20th c. and until the time the state gained independence, the Ukrainian geopolitical view had been formed; it took place in specific conditions (territorial and social dissociation, political terror) and directly influenced the geopolitics, which the state began to follow after it gained independence in 1991.

Moreover, at each historical stage of Ukrainian statehood formation, its geopolitical view changed also and was described in the works of those who

\section{sciendo}


were interested in the future of the state, justified the need for its autonomy or independence and cared about the future of Ukrainian ethnical lands. Many researchers, especially in the 20th c., have tried to develop different versions of state unions in which the participation of Ukraine could be beneficial for it, strengthening its geopolitical location and developing interests of other states towards it. Each one of the researchers substantiated the expediency of his own ideas, but they all agreed on the common opinion - the mandatory independence of ethnic Ukrainian lands and the formation of Ukraine as an independent state, independent of the aspirations or desires of other states. In addition, their proposed variants for possible alliances can be used by the state at the present stage in order to achieve the most useful results in practice.

Since Ukraine's independence, its geopolitical view has gradually transformed into geopolitical interests, which in turn have been determined by the peculiarities of its geopolitical location as well as the level of internal development of the state. Moreover, Ukraine occupies a very unique geopolitical location, which has both advantages and disadvantages. It is advantageous as the country is at the crossroads of strategically important trade routes, it is also the geographical centre of Europe, situated at the intersection of two worlds - Western with the European Union (EU) and the North Atlantic Treaty Organization (NATO) and Eastern with strong political and economic leaders such as Russia, China, India and others. Though extremely advantageous, the geopolitical location of the state is at the same time a difficult one, because Ukraine is located within the buffer zone, the territory where the interests of the regional leaders such as the EU and Russia collide. This became one of the reasons why Ukraine is still unable to determine the vectors of its geopolitics and which one of them should be implemented first. When Ukraine announced its European integration intentions, it provoked Russia's aggression against the state, which led to the annexation of Crimea by Russia and the spread of separatist tendencies within the state borders and this has an extremely negative impact on its internal development. In addition, there are several internal problems in the state, including the incomplete formation of state borders, demographic crisis, problems of pollution, cultural heterogeneity and others. The fact that with every new government the goals and directions of its foreign policy are radically changed negatively affects the development of the state. Moreover, even after 30 years of Ukrainian independence, its geopolitical principles and ideas still have not been clearly formed, those which could be implemented on a permanent basis and not changed in reality. With the sustainable implementation of those principles and ideas, the state could benefit from its economic, political, cultural, informational, security development.

In addition, Ukraine is in the field of geopolitical orientation of many countries. That's why foreign researchers may find it useful to understand the peculiarities of the formation of Ukraine's geopolitical view, which has passed a long period of development, to realise how closely the geopolitical view and history of Ukrainian statehood formation are linked, how the geopolitical view of Ukraine changed after its independence, and how it gradually transformed into the geopolitical interests of the state. It may prove important to study at what levels they should be implemented and how they are related to the geopolitical location of Ukraine. All of the above-mentioned issues were presented in the research paper.

To find information in a foreign language about the history of the formation of Ukraine's geopolitical view, as well as analyses of the works of researchers who developed it, is an extremely difficult task. The study of this issue was the main purpose of the research and formed the basis for choosing its topic, namely, the study of historical stages of the formation of Ukraine's geopolitical view as well as the peculiarities of its transformation at the present stage.

\section{Theoretical and methodological frameworks}

\section{Review of the research topic in scientific literature}

Any scientific research in the field of geopolitics requires deep theoretical knowledge; hence, theoretical books on geopolitics were used for making scientific research for this article. Works of such authors as Kolosov and Mironenko (2005), Yatsenko et al. (2007) deserve special attention, as 
they describe all possible approaches to the interpretation of geopolitics as a science, study the historical stages of its formation, as well as analyse the importance of categories used in it. Another author Gyorgy (2013), in his work, studies the influence of the German school of geopolitics on the evolution of this science around the world.

Political science explanatory dictionary (Politolohichnyy 2020) and a dictionary-reference book on geopolitics (Dergachov 2009) helped to distinguish two categories such as geopolitical view and geopolitical interest. The article also explains why the geopolitical view evolved into geopolitical interest after Ukraine achieved independence.

To substantiate the methods and explain how they were used in the article, the works of such scientists as Pashchenko (2010) and Topchiyev (2005) were studied.

As Ukraine is a relatively young state and the historical process of formation of its geopolitical view was long and difficult, there was a need to use such scientific works that would help to analyse comprehensively the history of Ukrainian statehood and history of formation of its political and geopolitical ideology. In order to fulfil this task, the works of such authors as Dnistryanskyj (2007, 2010, 2011), Dergachov (1996), Kaminsky (2005), Kukhta (1994), Shabliy (1993), Kapustyan (2016), Krushinsky and Levenets (1993), Krypyakevych (1995) as well as the works of those classics of geopolitics in Ukraine that directly influenced its formation in the 20th c., including Dziuba (1990), Kubiyovych (1943) and Lypa (1942) were studied and used for this scientific research.

It should be noted that despite the fact that the topic of the formation of Ukraine's geopolitical view and its evolution is complex and important, insufficient attention is paid to its study. Only a small number of scientists, including such as Dnistryanskyj (2000, 2008), Gvozdj (2020), Madison and Shakhov (2003), Chernyk, (2017) and Galjchynskyj (2002) work on comprehensive study of the geopolitics of Ukraine. Some aspects of Ukrainian geopolitics, features of its implementation and problematic issues are studied among domestic authors such as Bahrov (2002), Chernyk (2017), Doroshko and Shpakova (2011), Martsikhiv and Shepelyak (2020), Panchenko (2019), Pyrozhkov (2000), Shulga (2009), Vasylenko (2000), Zinko (2012), Zinyak (2014) and others.
Issues related to the geopolitics applied and state development strategies are partially covered in the periodicals, analysed on the website of the Ministry of Foreign Affairs of Ukraine (Minsterrstvo 2021), the publications of independent information and analytical centres such as the Razumkov Center (Ukrayins'kyy 2021), studied in publications of Victor Gvozd's geopolitical diary (Heopolitychnyy 2021), the scientific bulletin Geopolitics of Ukraine: History and modernity (Heopolityka 2021), the scientific journal National Security and Defense (Zhurnal 2021) and others.

Ukraine's place in the geopolitics of other countries and their orientation towards it can be found in the works of such foreign authors as Brzezinski (2000, 2006), Dergachov (2009, 2011), Larrabee (2010), Suremain and Verluise (2014), Terranova (2020) and Störk (2015), but their research is not sufficiently relevant to the analysis of Ukraine's geopolitics, mostly covering issues of Ukraine's place in the geopolitics of the countries they represent and the geopolitical orientation of these countries towards Ukraine.

Hence, the research on the history of the formation of Ukraine's geopolitical view and current transformation is relevant and topical as it can help to explain main features and problems of the state's modern geopolitics, and can be useful and interesting for researchers from abroad.

\section{Methodical bases for the research of historical stages of the state's geopolitical view formation and its modern transformation}

The study of the historical periods of the formation of Ukraine's geopolitical view and current transformation demands using exact and true methods, among which literary, historical, chronological, diachronic (periodisation method), system approach, event and content analysis, and SWOT analysis were applied in this article. Moreover, the definitions and descriptions, which were taken from the works of such authors as Panchenko (2019) and Topchiyev (2005) were used.

First of all, the literary method was employed for the implementation of the scientific research and it means 'the study of various sources of information related to the research problem'. 
Thanks to the analysis of primary, secondary and tertiary sources of information, it was possible to perform a thorough scientific study on the peculiarities of the formation and modern transformation of the geopolitical view of Ukraine.

In the article, a historical method was also used, which allowed conducting a retrospective analysis and establishing causal links related to the peculiarities of the formation and evolution of the geopolitical view of Ukraine. The historical method is closely related to the chronological method, the use of which made it possible to study the evolution of the main geopolitical ideas, to consider the work of various authors on this issue and to present them in a chronological order. Further, the diachronic method was applied to highlight the historical stages of the formation of the geopolitical view of Ukraine and substantiate their expediency.

In the process of writing the article, a systematic approach was also used, which involved the study of the evolution and implementation of the geopolitical view of the state as a holistic, systemic phenomenon. The application of this method helped not only to study the peculiarities of the formation of the geopolitical view of Ukraine at different historical stages, but also to analyse the peculiarities of its transformation at the present stage, taking into account the main interrelated preconditions-historical, political, legal, socio-economic and cultural.

Content and event analyses were also used for the scientific research in the article. Content analysis is based on the study of official information materials. Event analysis is a method of public information study, which allows investigating and systematising actions in international relations. The use of these methods made it possible to comprehensively study all possible factors of political, historical, cultural and economic nature that have a direct impact on the formation of Ukraine's geopolitical view and the implementation of its modern geopolitical interests.

Furthermore, the forecast method was employed as it helps to predict future situations and processes by the accumulation of a set of methods and techniques of research. Hence, by using this method, it became possible to anticipate possible threats and prospects in the pursuit of geopolitical interests of the state and to implement SWOT analysis of Ukraine's geopolitical location.
SWOT analysis, used in the article, deserves very special attention, as it is the basic algorithm for studying the situation based on the selection of strengths, weaknesses, opportunities and threats of the studied object and establishing links between them, the study of which allows designing a strategy for a behaviour pattern in a given situation. The article includes SWOT analysis of the geopolitical location of Ukraine, and is represented in a matrix of its strengths and weaknesses, opportunities and threats, the analysis of which made it possible to identify the main geopolitical interests of Ukraine at the present stage, as most of the current state's geopolitical interests derive from specific features of Ukraine's geopolitical location. The matrix was studied on the basis of such groups as 'strengths-opportunities', the study of which showed how to use most effectively the advantages of the geopolitical location of the state in pursuing its geopolitical interests, 'weaknesses-opportunities' - how to use opportunities to eliminate shortcomings, 'strengths-problems' - how the advantages of a geopolitical location can protect from external factors, 'weaknesses-problems' - what should be done to reduce existing problems or prevent possible as a result of negative influences of the state's geopolitical location. Thus, based on the geopolitical location of Ukraine SWOT analysis, it became possible to identify the main geopolitical interests of the state at the present stage.

Consequently, the use of all the scientific methods described above allowed a comprehensive analysis of the historical stages of the formation of the geopolitical view of Ukraine and features of its transformation at the present stage and made it possible to fulfil all the tasks which appeared during the implementation of this scientific research.

\section{The main historical stages of the formation of Ukraine's geopolitical view and features of its modern transformation}

\section{Origin and evolution of Ukraine's geopolitical view}

The geopolitical view of Ukraine has undergone a very long development process. The 
reason for this was a rather long absence of Ukrainian statehood, so various approaches to the vision of what Ukraine should be as an independent state, as well as which lands this state must include. Moreover, Ukraine has long been divided among different states, and from the middle of the 20th c. all its ethnic lands were under the control of the Soviet Union, where geopolitics was absolutely forbidden. Hence, until Ukraine got independence in 1991, we can only talk about the formation and development of its geopolitical view, which have formed the basis of the state's geopolitical interests since it got independence.

In general, the history of the formation of the geopolitical view of Ukraine can be divided into the following three key stages.

- Historical Stage 1. Primary, which began in the 9th c. and lasted until the beginning of the 20th c., was characterised by the appearance of the first sources of territorial and political information; the emergence of the first ideas about Ukraine's geopolitical subjectivity; substantiation of the principles of its political, legal and geopolitical views and the first attempts towards Ukrainian statehood formation.

- Historical Stage 2. Fundamental (the early 20th c.-1991) was characterised by the strengthening of national and political movements in Ukrainian ethnic lands; the emergence of the first scientifically based geopolitical ideas and visions; the scientific research of the first classics of the geopolitical view of Ukraine.

- Historical Stage 3. Modern (from the time of Ukraine's independence in 1991 until now) is characterised not only by the formation of Ukraine as an independent subject of international relations, but also by its awareness of its own geopolitical significance; formation of geopolitical priorities of its development, geopolitical orientation at regional and global levels; and, as a consequence, transformation of the state's geopolitical view into its geopolitical interest.

The characteristic features and main achievements of Historical Stage 1 of Ukraine's geopolitical view formation are represented in Table 1.

Historical Stage 1 in the formation of Ukraine's geopolitical view dates back to the 9th c., when the Ukrainian lands became the centre of Kievan Rus - one of the largest and most powerful states of the Middle Ages, which in 1240 was ruined and became dependent on the Mongol Empire. After that time, the political, economic and cultural centre of the Ukrainian lands moved to the Galicia-Volyn state (the territory of modern Western and South-Western Ukraine), which in the late 14th c. was divided between the Kingdom of Poland and the Grand Duchy of Lithuania (Kapustyan 2016).

During this period the first sources of territorial and political information about Ukrainian lands appeared, including the chronicles of Kievan Rus and the Galicia-Volyn state, which described the territory of Kievan Rus, division into tribes, the nature of dynastic relations and Rus's place in the system of foreign relations of the time. With the loss of Rus (ancient Ukrainian) statehood during the 13th c. and 14th c., the need to restore it and fight for the identity of Ukrainian lands existed only in church-educational circles.

At the end of the 14th c., southern Ukrainian lands became under the control of the Crimean Khanate; Transcarpathia - Hungary; northern, central and partly western lands - Lithuania and south-western territories belonged to Poland, which in the 14th c. united with Lithuania, creating the Polish-Lithuanian Commonwealth.

In the 15th c. in the territory of the so-called 'wild steppes' of the South, there appeared a group of soldiers who called themselves 'Cossacks' and they formed a separate social class, which managed in 1648-1657 to raise an uprising led by Bohdan Khmelnytsky (15961657) and create a self-governing Ukrainian state in modern central Ukraine - 'Zaporizhzhya Sich' (Krypyakevych 1995).

The period of the Cossacks and their active struggle resulted not only in the formation of a new Ukrainian state but also brought a new geopolitical worldview. The new geopolitical thinking also affected the activities of hetman governments in the international arena, for example, in attempts to create broad interstate coalitions, as well as to sign important political treaties of that time. Moreover, cartographic materials and descriptions of the French engineer Boplan (1600-1673) confirmed the perception of Cossack Ukraine as a separate territorial and political unit in the international arena.

No less important was the constitution of Hetman Pylyp Orlyk (1672-1742), adopted in 
Table 1. The characteristic features and achievements of Historical Stage 1 of Ukraine's geopolitical view formation.

Historical Stage 1 (9th century-early 20th century) - primary

Main features:

- first attempts at Ukrainian statehood formation;

- emergence of first ideas about Ukrainian geopolitical subjectivity;

- evaluation of the role and importance of Ukrainian ethnic lands inside and outside the states to which they belonged;

- germination of first Ukrainian geopolitical view.

\begin{tabular}{l}
\hline \multicolumn{1}{|c|}{ Main sub-stages and their historical features } \\
\hline Sub-stage 1a (9th c.-15th c.) \\
From the 9th c. to the middle of the 13th c. Ukrainian \\
lands became the centre of Kievan Rus, and from the \\
13th c. to the 14th c. - the Galicia-Volyn state (West and \\
South-West territories). \\
At the end of the 14th c., Ukrainian lands became under \\
the rule of Lithuania (northern, central and partly west- \\
ern lands) and Poland (southwestern territories) - in the \\
16th c., both states united in the Commonwealth; the \\
southern steppe of Ukraine was under the rule of the \\
Crimean Khanate, formed in 1447, and Transcarpathia \\
under the rule of Hungary.
\end{tabular}

Sub-stage 1 b (15th c.-18th c.)

In the 15th c., in the southern territory of wild steppes

Cossacks appeared, who formed a special social sta-

tus of warriors. In the middle of the 17th c., under the

leadership of Bohdan Khmelnytsky, they created a self-governing Ukrainian state on the territory of modern central Ukraine - 'Zaporozhian Sich', which was finally destroyed in the 18th $\mathrm{c}$.

\section{Sub-stage 1c (18th c.-early 20th c.)}

From the end of 18th c., Ukrainian ethnic lands were divided by Austria-Hungary (western and south-western territories) and by the Russian Empire (received the rest).
- as a result of the liberation war, Ukrainian statehood was restored;

- hetmans' governments were oriented towards creating broad international coalitions;

- important international agreements were signed;

- the first cartographic materials and descriptions of Ukrainian lands by foreign researchers appeared, like works of the French engineer Boplan (1600-1673);

- in the Constitution by Orlyk (1710) the basic democratic principles of the independent Cossack Ukraine political organisation were explained.

In the territories belonging to Austria-Hungary:

- representatives of the 'Russian Trinity' substantiated the idea of the unity of Ukrainians in the West and East and their separation from the Poles and Russians and demanded the autonomy of Ukrainian lands in Galicia (south-western territory);

- based on socialist consideration, the idea of an independent Ukraine was developed by the first political parties, which was explained in the work 'Ukraine irredenta' by Bachynsky (1895).

In the territories belonging to the Russian Empire:

- in 1845-1846, representatives of the Cyril and Methodius Brotherhood developed the idea to create a Slavic Federation, one of the leading republics of which Ukraine had to be;

- in the works of Drahomanov (1841-1895) the idea of Ukrainian autonomy as a part of federal Russia was proclaimed;

- during this period, there was an increase in the number of scientific works on the study of Ukrainian people, including the first map of the settlement of Ukrainians by Velychko (1896); ethnic map of Subcarpathian Rus by Tomashivsky (1910); works of ethnographers, historians, conclusions of linguists.

Source: compiled and developed by the author. 
1710, which formed the basic democratic principles of the political organisation of independent Cossack Ukraine, despite the fact that in political and geographical terms this document had a number of shortcomings, for example, it limited the territory of the Cossack state to the temporarily determined variant by the Polish king during the national liberation war led by Khmelnytsky.

After the destruction of Cossack autonomy in the late 18th c., all Ukrainian ethnic lands became divided between the Russian Empire and AustriaHungary. The idea of Ukrainian statehood was preserved for a long time on the territory of previous Hetmanate, belonging from those times to the Russian Empire. Thus, in the late 1845 and the early 1846, the Cyril and Methodius Brotherhood emerged in the statute, which, under the influence of Slavophilic ideas, defined its political ideal-the Slavic federation with Ukraine as one of the leading republics (Kukhta 1994).

At the same time, the Ukrainian geopolitical view developed in the western lands of Ukraine, which from the end of the 18th c. became part of the Austrian Empire, and from 1867-the AustroHungarian Empire. An important political and geographical significance here was the proclamation of the unity of Ukrainians (Rus people) by the 'Rus's Trinity' in the west and east and their separateness from Poles and Russians. One of its members, Holovatsky, in 1846 announced the first political demand-autonomy for the Ukrainian lands in Galicia. Also, the Rus-Ukrainian radical party of social-democratic type, formed in 1890, at its first congress (1895) announced the idea of an independent Ukraine, substantiated from socialist positions and described in the work of Bachynsky 'Ukraine Irredenta' (1895) (Dergachov 1996).

At this time, on the territory of the Ukrainian lands that were part of the Russian Empire, the idea of an autonomous Ukraine, as part of a federal Russia was concretised, according to Drahomanov (1841-1895), an author who was a public figure. He also proposed to improve the administrative division of the Russian Empire, taking into account ethnic characteristics, substantiated the need for Ukrainians to explore the Black Sea region and proved the necessity to strengthen the Ukrainian geopolitical position in the region and was the first to pay much attention to the importance of geopolitical location and relations with the neighbours.
In 1900, Mikhnovsky (1873-1924) in his work 'Independent Ukraine' paid much attention to geopolitical relations, especially to the intensification of political movements of enslaved peoples, and as a consequence - to the formation of the state independence of Ukraine throughout the ethnic territory 'from the Carpathians to the Caucasus'.

What positively affected the formation of the Ukrainian geopolitical consciousness of those times was the publication of a large number of scientific works on geography and identity of the Ukrainian people divided between the two states. They included the first map of the settlement of Ukrainians by Velychko (1986), the ethnic map of Subcarpathian Russia by Tomashivsky (1910), works of historians Antonovych, Hrushevsky, Bagaliy, Korduba, works of ethnographers Chubynsky, Sumtsov, Hnatiuk, Vovk and conclusions of linguists Potebny, Mykhalchuk, Zhitetsky and others (Dnistryanskyj 2007).

The beginning of the 20th c. saw Historical Stage 2 of Ukraine's geopolitical view formation (Table 2), the main features of which are the strengthening of national political movements, appearance of a new geostrategic thinking about the future of Ukraine, research of possible prospects of Ukrainian statehood and theoretical substantiation of geopolitical ideas and views.

After the collapse of the Russian empire in 1917, the prominent historian Hrushevsky (18661934) had a decisive influence on the formation of the geopolitical consciousness of the Ukrainian people in sub-Russian Ukraine. The author paid much attention to the history of Ukraine, which, in his opinion, determined the identity of Ukrainians and their special way of life. However, he saw the future of Ukraine as an autonomous component of the Russian Federation, whose territory was to include provinces with a predominant Ukrainian population (Krushinsky, Levenets 1993). In January 1917, after the capture of Kyiv by the Bolsheviks, Hrushevsky began to defend the idea of the full state independence of Ukraine, however, in his works he didn't want the Ukrainian people to dominate, because it demoralised and couldn't be combined with democracy. Thus, the author opposed the idea of Ukrainian imperialism in every possible way (Dnistryanskyj 2010).

The works of the Ukrainian geographer Rudnytsky (1877-1937), who paid considerable 
Table 2. Characteristic features and achievements of Historical Stage 2 of Ukraine's geopolitical view formation.

Historical Stage 2 (early 20th century-1991) - fundamental

Main features:

- strengthening of national and political movements;

- emergence of the first scientifically developed geopolitical ideas and visions;

- study of possible geopolitical alliances for the pursuit of Ukrainian interests;

- at the beginning of the 20th c., establishment of the Ukrainian People's Republic and the Western Ukrainian People's Republic, with their subsequent unification;

- from the mid-20th c., unification of the entire Ukrainian territory within the Ukrainian Soviet Socialistic Republic as a union republic of the USSR (Soviet Union).

As a result of the overthrown of the monarchy and the Bolshevik revolution in Russia in 1917, professor Mykhailo Hrushevsky formed the Ukrainian People's Republic in Kyiv, which, after the beginning of the Ukrainian-Bolshevik war in 1918, declared its independence and concluded an agreement with Germany and the Austro-Hungarian Empire. After the capitulation of Germany in World War I, the Bolsheviks created the

Hี Ukrainian Socialist Soviet Republic in 1919 in Kharkiv and established Soviet control in Central, Eastern and Southern Ukraine until 1920.

The disintegration of the Austro-Hungarian Empire in October 1918 resulted in the formation of the Western

Ukrainian People's Republic, which lasted until the beginning of 1921, when the western territories of Ukraine were ceded to Poland and the south-western territories to Romania and the Czech Republic. In the 1920s and

1930s in Western Ukraine, an anti-Polish liberation movement (the Organisation of Ukrainian Nationalists) was

created, with the goal to establish a Ukrainian conciliar independent state; this movement continued its clandes-

tine activities even after Western Ukraine's accession to the Ukrainian Socialist Soviet Republic.

In 1922, the Ukrainian Soviet Socialist Republic, together with the Bolshevik republics of Russia, Belarus and the Caucasus, concluded an agreement on the formation of the USSR, by which all western and south-western territories of Ukraine were ceded to the Ukrainian Socialist Soviet Republic during World War II, hence, from that time until Ukraine's independence, all the territories of modern Ukraine became part of the Soviet Union.

- substantiation of the idea of a full state independence of Ukraine and expediency to consider its territory on the ethnic principle in the works of Hrushevsky (1866-1934);

- in the works of Rudnytsky (1877-1937) - analysis of the world geopolitical system and the place of Ukraine in it; proof of the necessity of Ukraine's independence and the creation of Galician statehood as its intermediate variant; substantiation of the priority of the national rather than geographical principle in the formation of the states of a new Europe; substantiation of the idea of the Baltic-Pontic Federation, as opposed to Russian expansion;

- as a result of the activities of Skrypnyk (1872-1933) and other national democrats, support was given to ethnic Ukrainians outside the Ukrainian Socialist Soviet Republic, and the expediency of expanding its borders at the expense of neighbouring ethnic Ukrainian territories was developed;

- Synyavsky (1866-1951) studied in his works the geopolitical processes in Europe; substantiated the expediency of 'Pan-Europe' formation; studied the economic interests of the USSR in the Middle East;

- Khvylovy (1893-1933) substantiated in his works the need to reorient Ukrainian literature to Europe and overcome dependence on Russian culture;

- in the works of Bochkovsky (1884-1939) the theoretical basis of ethnopolitics was formed, the author considered it as a science that studies the specifics of the relationship between nation and state;

- in the works of Lypynsky (1882-1931) a sociological theory was developed, where the nation was formed based on 'territorial patriotism'; the author studied the issue of cultural division of Ukrainians and the need for their harmonious combination;

- the idea of creating the Adriatic Union (Ukraine, Czechoslovakia, Balkan Slavic countries) based on mental and historical commonality in the works of Tomashivsky (1864-1938) and Shelukhin (1864-1938) was developed;

- substantiation of the idea of the 'Black Sea Doctrine' in the works of Lypa (1900-1944), in which the Black Sea basin had to unite the territories that belonged to it into a powerful political unit;

- in the works of Kubiyovych (1900-1985), the right of Ukrainian ethnic lands to unite into a single Ukrainian state was proved; the author politically and geographically substantiated and supported the independence of Carpathian Ukraine;

- as a result of the activities of the 'main liberation council' formed in July 1944, the idea of the formation of the Ukrainian independent conciliar state was developed and the idea of cooperation with all the enslaved peoples of Europe and Asia was proclaimed;

- in the works of the intelligentsia of the emigrant movement in the 1950s, ethnopolitical and geopolitical problems of the Ukrainian people were studied and the idea that the balance of nation-states can become a guarantee of a new international order was developed. 
Historical Stage 2 (early 20th century-1991) - fundamental

\begin{tabular}{l|l} 
- Sosnovsky (1919-1975) in his works analysed the activities of Ukrainian foreign forces and studied the reasons \\
for the lack of their significant results;
\end{tabular}

Source: compiled and developed by the author.

attention to the study of the world geopolitical system and the place of Ukraine in it (Shabliy 1993), were the culmination of the achievements of the 20th-century geopolitical ideas. In 1916, in Vienna, Rudnytsky published the work 'Ukraine from the political-geographical view' in German, in which he proved the necessity and inevitability of Ukraine's independence, taking into account all historical and ethno-political factors. Rudnytsky substantiated the fact of the temporality of multinational empires and used this argument to explain necessity of an independent Ukraine formation within its ethnic borders, moreover for the security and stability of Central and Eastern Europe. In addition, the author substantiated the idea of the Baltic-Pontic Federation, as opposed to Russian expansion and justified the inadmissibility of Ukraine's accession to the Russian Federation, which could only strengthen its expansionist ambitions and provoke Russia's annexation of Central Europe.

After the defeat of the national revolution of Ukraine in 1921, for the next two decades the Ukrainian ethnic lands were divided between four states: the western and south-western territories of the state became part of Poland, Czechoslovakia and Romania; all other lands became part of the Soviet Union, where the Ukrainian Soviet Socialist Republic was established (Istorychna 2021). In the Ukrainian territory under the Soviet Union, the influence of national communists started to grow and spread over in the subsequent years. National communists supported Bolshevism, but tried to pursue a policy of 'Ukrainisation'. Their bright representative Mykola Skrypnyk (1872-1933) tried to support ethnic Ukrainians outside the Ukrainian Soviet Socialist Republic and even managed to justify revision of its borders with the subsequent inclusion of the neighbouring ethnic Ukrainian territories.
In later years, Ukrainian lands under the Soviet Union faced anti-Ukrainian ethnocultural and socio-economic policies, which were more criminal in nature (organisation of the famine, mass repressions, deportations). Despite the suppression of all possible manifestations of Ukrainian independent political thought and activity, representatives of the 'old Ukrainian intelligentsia' continued to be active, for example Synyavsky (1866-1951), who carefully studied geopolitical processes in Europe, as well as economic interests of the Union of Soviet Socialist Republics (USSR) in the Middle East. What was also interesting were the views of the famous writer and publicist Mykola Khvylovy (1893-1933), who substantiated the need to reorient Ukrainian literature to Europe and overcome psychological dependence on Russian culture. The works of Bochkovsky (1884-1939) were also important; the author laid the foundations for the doctrine of the nation (nationalism) and developed the theoretical foundations of ethnopolitics as a science that studied the specifics of the relationship between nation and state at all levels of its manifestation (Dnistryanskyj 2011).

In the interwar period, Lypynsky (1882-1931) actively worked on the formation of a sociological theory in which the nation was understood as a unity of citizenship and was characterised by 'territorial patriotism'. The author actively studied the issues of internal geocultural scission between ethnic Ukrainians who were divided between several states and would have to be harmoniously united based on culture and other issues.

During this period, new ideas of possible geopolitical alliances with the inclusion of Ukraine appeared. For example, the historian Stepan Tomashivsky (1864-1938) and politician Serhiy Shelukhin (1864-1938) developed the idea of the formation of the Adriatic Union, which had to 
include Ukraine, Czechoslovakia and the Balkan Slavic countries based on their mental and historical commonality. The views of Lypa (19001944), who proposed the creation of the Black Sea union, are also very interesting (Lypa 1942). Having great potential, the Black Sea basin created integrity between the countries that belonged to it. In addition, Lypa also foresaw the collapse of the Soviet Union and independence of its constituent republics.

The works of the Ukrainian demographer and ethnogeographer Volodymyr Kubiyovych (1900-1985) were also very interesting. He edited and published books on the geography of nonstate Ukraine and his works drew attention to the Ukrainian question of foreign scholars and politicians. As a result, Ukrainian ethnic lands began to be considered as having all potential rights to unite into a single Ukrainian state. Also, the author supported the question of Carpathian Ukraine independence (Kubiyovych 1943).

In 1944, as a result of events at the time, on the territories of the Ukrainian Soviet Socialistic Republic, the Ukrainian main liberation council was established as the supreme body in the revolutionary liberation struggle for the Ukrainian independent conciliar state, which functioned on democratic national principles. It promised to cooperate with all the enslaved peoples of Europe and Asia, who fought for their independence and recognised the same right of Ukraine.

At that time, the Ukrainian representatives of clandestine activity became also active. For example, Fedun (1919-1951) in his works studied the question of Ukraine's place in the system of international relations. The author proved that history created all the conditions for the formation of independent nation-states, and this process was organic and natural. He actively studied such concepts as 'the idea of the nation', 'the idea of a democratic constitutional-parliamentary republic'. The author pointed out the imperfection of international relations of that time, which did not provide proper conditions for self-determination of peoples, when large states operated on such concepts as 'strategic positions' and 'strategic boundaries' (Dergachov 1996).

In the mid-20th c., the emigrant movement intensified; its representative Lev Rebet (1912-1957) in his book 'Theory of the nation' (1956) tried to justify the idea that the cause of military conflicts was the national self-determination of states and, in his opinion, the world was threatened not by small sovereign states, but by large multinational ones, which strived to expand the boundaries of their domination as much as possible.

During that time, the emigrant 'Ukrainian Magazine' was also published, which included the works of Kaminsky. The author proved that just balance of nation-states, as a consequence of healthy and true nationalism and internationalism, could become a guarantee of a new international order, as it could create an organically balanced international system (Kaminsky 2005). The author also criticised the American geopolitics of USSR containment, developed by the leading American geostrategist George Kennan, because of his incorrect interpretation of the prospects of the Ukrainian state.

In 1966, Sosnovsky (1919-1975) in his work 'Ukraine in the international arena' tried to explore the activities of various Ukrainian foreign forces and studied the reason for the lack of their significant results. In his opinion, it stemmed from the fact that they failed to create a common centre and acted in most of the cases in different vectors.

After the official condemnation of the cult of Stalin in 1956, during the so-called period of 'Khrushchev's thaw' in the USSR, the activities of a new generation of young creative intelligentsia, mostly literary, called the 'sixties' intensified. They did not doubt the official Soviet ideology, but raised the problem of Ukrainian language and the necessity to develop Ukrainian culture. In the work of their representative Ivan Dzyuba 'Internationalism or russification', which was written in 1965, but officially published and widespread only in 1990 (Dziuba 1990), the crisis of Ukrainian culture was explained, which within the Soviet Union was considered second-rate and provincial.

The activity of the 'sixties' was quite short as in the second half of the 1960s they were subjected to mass repression. However, they created the basis for Ukrainian 'dissidentism' - the resistance movement to the Soviet regime (1970-1980), in all spheres of public life (Dnistryanskyj 2010). During the 1980s, the dissident movement was practically defeated, but it managed to influence the ideological visions and worldview of the population not only within the ethnic Ukrainian 
lands, but it also changed their views about their future abroad.

As the result of the evolution of the geopolitical view of Ukraine on August 24, 1991, the state attained its independence. Historical Stage 3 of the formation of Ukraine's geopolitical view began with its independence in 1991 and continues to this day. However, this stage has a very specific feature, as since the independence of Ukraine, its geopolitical view has been gradually transformed into the geopolitical interest, which is a system of goals and objectives in the process of the state's geopolitics implementation.

\section{Substantiation of the main geopolitical interests of the state based on its geopolitical location SWOT analysis}

After Ukraine attained independence in 1991, its geopolitical view was changed dramatically as in the past periods the main ideas it struggled for was independence of the state. After 1991, Ukraine faced a big number of new challenges and problems. Nevertheless, after this time exact ideas how the state must develop, what must be made and solved appeared. As these ideas developed on the basis of a scientific approach and remained actual for a long period of time they can be called geopolitical interests of the state. Moreover, geopolitical interests of independent Ukraine derived from the geopolitical view of Ukraine before its independence, and were influenced by its geopolitical location and realities of modern times. They were explained in works of various modern researches which were mentioned in the paragraph 'Review of the research topic in the scientific literature' of this article and will be studied in the text which follows.

The primary task for identifying and substantiating the objective geopolitical interests of Ukraine at the present stage is to evaluate its geopolitical location, which is both profitable and quite complex. One of the difficulties is due to the fact that the issue of regional affiliation of the state is still unresolved. After all, most scientists and researchers consider Ukraine regionally exclusively a European state (Pyrozhkov 2000).

In turn, Dergachov (2011) considers Ukraine a bi-regional state, which means its peripheral position in relation to two regions-Europe and Eurasia. According to the scientist, the state is interested in developing its bi-regionalism and maintaining constructive international relations between Europe and Eurasia. The fact is that Ukraine is characterised by an average level of economic development internationally and it is under increasing pressure from Russia, the United States and the EU. Therefore, the lack of state tradition as well as a clearly defined conceptual foreign policy determines the uncertain geopolitical orientations of Ukraine.

Brzezinski $(2000,2006)$ in his works assigns Ukraine the role of a 'buffer zone' between such centres of economic power as the EU and Russia and between such centres of political and military forces as NATO and Russia. In addition, the scientist believes that Western politicians evaluate Ukraine only through the prism of their relations with Russia.

Table 3, given below, offers a SWOT analysis of the geopolitical location of the state, developed by the author personally, which became possible after studying the data provided in the works of such authors as Babenko et al. (2020), Chernyk (2017), Gvozdj (2020), Dnistryanskyj (2000, 2008), Dzhaman and Shukanov (2007), Klyuchko (2002), Skitsj (2015), Vasylenko (2000) and others.

On examining the data presented in Table 3, it becomes possible to understand how interconnected the strengths and weaknesses of the geopolitical location of the state are, how weaknesses affect the formation of threats and strengths become the basis for opportunities. Moreover, threats and opportunities are also interconnected, as insufficient use of geopolitical opportunities by the state leads to the situation in which the number of threats will increase in the future. In turn, making the most of all opportunities will reduce and prevent possible threats.

From the data shown in Table 3, it becomes evident, that Ukraine occupies both favourable and at the same time very complicated geopolitical location. On one hand, Ukraine's geopolitical location gives plenty of opportunities for the development of the state. These are: sufficient use of its transit potential and developed roads for strengthening the state's geopolitical potential; possibility of developing cooperation with neighbouring states-especially the EU countries in order to reduce the negative influence of Russia; implementation of all possible tools and methods to weaken the status of Ukraine as a buffer-zone 
Table 3. SWOT analysis of the geopolitical location of Ukraine.

\begin{tabular}{|c|c|}
\hline & ristics \\
\hline & $\begin{array}{l}\text { - the state territory has unique natural conditions, including sufficiently fertile soils, a significant amount of } \\
\text { minerals, favourable climatic conditions; } \\
\text { - sufficient road development and Ukraine's access to the seas; } \\
\text { - significant length of state borders; } \\
\text { - location of the state's territory in the geographical centre of Europe and geographically advantageous location } \\
\text { of Ukraine on the cross-border of Europe and Asia - trade routes between Europe and Asia intersect in its } \\
\text { territory; } \\
\text { - the state's membership in the Baltic-Black Sea-Caspian region and its transit position between the Caspian } \\
\text { region, the Middle East and Europe; } \\
\text { - Ukraine's international transit potential related to its position in the pan-European transport zone of the Black } \\
\text { - Sea basin; } \\
\text { - favourable transit position of Ukraine for the transport of Russian energy to Europe; } \\
\text { - institutional cooperation of the state with a large number of international organisations of regional and global } \\
\text { nature and Ukraine's participation in the formation of regional integration within the Baltic-Black Sea-Caspian } \\
\text { region (the Organization for Democracy and Economic Development (GUAM) and The Black Sea Economic } \\
\text { Cooperation (BSEC). }\end{array}$ \\
\hline & $\begin{array}{l}\text { - cultural, mental and ideological differences between the East and the West of the state, their insufficient con- } \\
\text { nection in the process of historical formation of Ukrainian statehood; } \\
\text { - problems with the demarcation of the land border with Belarus and Moldova and lack of a maritime border } \\
\text { - with Russia; } \\
\text { - diversity of views about the state's regional affiliation and orientation; } \\
\text { - Ukraine's dependence on the Russian energy transport and insufficient provision of the state with its own } \\
\text { energy resources, as well as insufficient use of alternative energy resources; } \\
\text { - suboptimal geographical structure of foreign trade relations (predominance of regional cooperation over } \\
\text { international). }\end{array}$ \\
\hline & $\begin{array}{l}\text { - introduction of an effective regional policy to overcome the disparities in regional economic development; } \\
\text { - implementation of all possible means to overcome the demographic crisis and the return of Ukrainian labour } \\
\text { migrants to their homeland; } \\
\text { - ensuring a system of optimal relations between ethnic Ukrainians and ethno-national minorities; } \\
\text { - purposeful formation of a positive and objective image of Ukraine in the world mass media; } \\
\text { - implementation of effective practical geopolitics within the state borders to eliminate problematic issues of } \\
\text { territorial and political integrity of the state, creating favourable conditions for its domestic and foreign policy } \\
\text { development; } \\
\text { - gradual, purposeful exit from the (political, economic, cultural and information) power field of Russia without } \\
\text { the use of provocative actions and with the preservation and strengthening of its position in the Russian } \\
\text { (sub-regional) market; } \\
\text { - formation and implementation of a geostrategy based on the priority of national interests, development of } \\
\text { aggregate capacity, greater international prestige and a comprehensive understanding of global and European } \\
\text { processes. }\end{array}$ \\
\hline & $\begin{array}{l}\text { - presence of a large number of political parties and diversity of their orientations; } \\
\text { - regional disparities in socio-economic development levels; } \\
\text { - ongoing serious demographic crisis, which was the result of population aging, declining birth rates and mass } \\
\text { illegal labour migration to better developed neighbouring countries; } \\
\text { - penetration of illegal migrants, contraband, goods, drugs and criminal groups through the problematic areas } \\
\text { of the border; } \\
\text { - existence of a common border with the self-proclaimed Transnistrian Moldavian Republic and the proximity } \\
\text { to the conflict-generating Caucasus region, which have become centres of political and military tension; } \\
\text { - geographical position of Ukraine in the so-called buffer zone between regional economic (EU and the Russian } \\
\text { Federation) and military-political centres of global power (NATO and the Russian Federation); } \\
\text { - expansionist policy and geopolitical pressure from Russia which are aimed at the dissociation of Ukrainian } \\
\text { society with further intentions of full control over the situation in Ukraine. As the result of such policy, since } \\
\text { 2014 bloody war in eastern Ukraine has begun and two self-proclaimed republics in its eastern territories have } \\
\text { been formed - Lugansk People's Republic and Donetsk People's Republic. Moreover, in 2014 Russia annexed } \\
\text { Ukrainian Crimea. }\end{array}$ \\
\hline
\end{tabular}

Source: compiled and developed by the author. 
state etc. At the same time, the geopolitical location of the state is very complicated as Ukraine is situated between two rival geopolitical leaders the EU and Russia. Moreover, the state is too close to hot points of Europe (the self-proclaimed Transnistrian Republic) and of Asia (self-proclaimed countries of the Caucasus region). Also, Ukraine has unresolved state borders issues due to the annexation of state territories by Russia and plenty of other problematic questions. To develop and propose the main geopolitical interests of Ukraine, SWOT analysis of its geopolitical location must be taken into consideration as it shows the main problematic issues which must be solved by the state and main opportunities that can positively affect the state's development.

Having analysed the strengths and weaknesses, threats and opportunities of the geopolitical location of Ukraine, as well as the works of such authors as Doroshko and Shpakova (2011), Martsikhiv and Shepelyak (2020), Panchenko (2019), Shulga (2009), Zinko (2012), information given on the website of the Ministry of Foreign Affairs of Ukraine (Minsterrstvo 2021) and in such information-analytical sites as Victor Gvozd's Geopolitical Diary (Heopolitychnyy 2021) and

Table 4. The structure of geopolitical interests of Ukraine at the present stage.

\begin{tabular}{l} 
1. Geopolitical interests at national level \\
\hline - protection of sovereignty, territorial integrity and security of the state and its population; \\
- fight against any manifestations of anti-Ukrainian activities such as separatism, political extremism, corruption, \\
attempts to federalise the state, etc.; \\
- completion of the anti-terrorist operation in the east of the state and resolution of contentious territorial issues \\
- within its borders; \\
- gradual reform of the state's defence sector in accordance with the main challenges of today or potential threats; \\
- overcoming cultural and ideological contradictions between the East and the West of the state; \\
- prevention of Ukrainian cultural and spiritual identity loss under the influence of external forces; \\
- providing the state with sufficient information support to protect its own interests and counteract external infor- \\
mation pressure.
\end{tabular}

\section{Geopolitical interests at regional level}

- diversification of energy supply sources and ways, reduction of energy dependence on Russia;

- ensuring stable political, economic and democratic development and as a result, the formation of Ukraine as a powerful regional leader;

- strengthening state participation in regional cooperation measures to combat piracy, terrorism, internationally organised crime, illegal transport of arms and illegal migration, as well as intensifying Ukraine's participation in Operation Black Sea Harmony to control shipping in the Black Sea;

- implementation of such foreign policy activities that would provide Ukraine with the status of a guarantor of stability in South-Eastern Europe and the Black Sea-Caucasus region.

\section{Geopolitical interests at global level}

- active support of the Ukrainian diaspora abroad and as a result, the formation of additional channels for the pursuit of the state's interests outside its borders;

- increasing the state's economic potential and its economic security by integration into the world economy, as well as into the European energy and transport system;

- the legal framework to improve the investment climate in Ukraine, protecting key sectors of Ukraine's economy from the possible foreign control, strengthening competitiveness of domestic products in domestic and foreign markets;

- further development and improvement of the state transport infrastructure to intensify its activities in the system of international transport corridors;

- balanced development of relations with the USA/NATO/EU with the further realisation of Ukraine's Euro-Atlantic intention.

- developing Ukraine's participation in the activity of international and regional organisations in which the country is a member;

- strengthening of Ukraine's participation in international peacekeeping missions, including its participation in solving the Transnistria and the Caucasus conflicts;

- combating the spread of the coronavirus pandemic, overcoming its effects and implementing measures to solve this problem at international level;

- Ukraine's formation as a strong independent subject of international relations, able to defend its own national interests, which does not depend on the geopolitical orientation of the neighbouring states and the ambitions of other regional leaders. 
Olesandr Razumkov Ukrainian centre for economic and political studies (Ukrayins'kyy 2021), this article points out the following categories of geopolitical interests of Ukraine: (1) geopolitical interests at national (state) level; (2) geopolitical interests at regional level; and (3) geopolitical interests at global level, which are represented in Table 4.

The implementation of the main geopolitical interests of Ukraine highlighted in Table 4 will ensure the state's sustainable development, solve the existing internal and external problems and will provide a basis for Ukraine to be a strong and independent participant of international relations, able to defend its own national interests.

\section{Conclusions on the accomplished scientific research}

As the result of the complex historical development of Ukrainian statehood, the formation of its geopolitical view was rather complicated. Moreover, from the time Ukraine got its independence, it was transformed to the state's geopolitical interest.

Based on the scientific research applied, the article proposed dividing the history of the geopolitical view in Ukraine into three stages. Historical Stage 1 (9th c.-early 20th c.) - primary - was characterised by the first attempts to restore Ukrainian statehood after the fall of Kievan Rus and Galicia-Volyn principality, which resulted in the division of ethnic Ukrainian lands among several neighbouring states, the appearance of the first geopolitical views about the future of Ukrainian lands and the definition of their role and importance in the system of international relations of that time. Historical Stage 2 (early 20th c.-1991) - fundamental - was characterised by the strengthening of national and political movements in the country, the nascency of the first scientifically justified geopolitical ideas and visions, the scientific research of the first Ukrainian geopolitical classics. It was during this period that all Ukrainian ethnic lands were united into one of the Soviet Union republics, and as a result gained their independence in 1991. Historical Stage 3 (from the time of Ukraine's independence in 1991-until today) modern - has been characterised not only by the formation of Ukraine as an independent subject of international relations, but also by its awareness of its own geopolitical significance, determination of geopolitical priorities of its development, formation of its geopolitical orientations at regional and global levels and, as a consequence, transformation of its geopolitical view into its geopolitical interests.

At the present stage, the main geopolitical interests of Ukraine can be divided into three key groups, such as geopolitical interests at national (state), regional and global levels. It became possible to single out and substantiate these geopolitical interests based on state geopolitical location using SWOT analysis. As strengths and weaknesses of the geopolitical location of the state are highly interconnected, weaknesses affect the formation of threats, and strengths become the basis for the opportunities. Moreover, threats and opportunities are also interconnected, as insufficient use of geopolitical opportunities by the state leads to the situation in which the number of threats will increase in the future. In turn, making the most of all opportunities will reduce and prevent possible threats. As a result, the article justified that Ukraine has occupied both favourable and complicated geopolitical position, being located in the territory of a so-called buffer zone between the interests of the EU and Russia. Nevertheless, owing to the state's realisation of geopolitical interests, it becomes possible to solve problematic issues of Ukraine's development and promote its formation as an active subject of international relations, independent of the neighbouring states' pressure.

\section{Acknowledgements}

This research has been carried out within the framework of the state budget scientific theme of the Department of International Relations and Regional Studios of Lesia Ukrainka Volyn National University called 'Ukraine in the System of the European Integration and the CrossBorder Cooperation'. Prospects for further research are related to the analysis of the formation of Ukraine's geopolitical interests, their problematic issues and perspectives of their implementation at the present stage, as well as analysis of the place of Poland in the geopolitical orientation of Ukraine and vice versa. 


\section{References}

Babenko V., Biletska Y., Pelyak H., 2020. Ukraine-EU: Economic integration strategy. Geopolitics under Globalization 3(1): 12-23. DOI 10.21511/gg.03(1).2020.02.

Bahrov N.V., 2002. Rehyonal'naya heopolytyka ustoychyoho razvytyya (Regional geopolitics of sustainable development). Lybid', Kyyiv (in Russian).

Brzezinski Z., 2000. Velyka shakhivnytsya (The Great chessboard). L'viv-Ivano-Frankivs'k: «Aileya-NV» (in Ukrainian).

Brzezinski Z., 2006. Ukrayina u heostratehichnomu konteksti (Ukraine in a geostrategic context). Vydavnychyy dim "Kyyevo-Mohylyans'ka akademiya", Kyyiv. (in Ukrainian).

Chernyk P., 2017. Heopolitychne polozhennya Ukrayiny $v$ Tsentral'no-Skhidniy Yeoropi. Dysertatsiya kandydata politychnykh nauk (Geopolitical position of Ukraine in Central and Eastern Europe. PhD thesis) L'vivs'kyy natsional'nyy universytet imeni I. Franka, L'viv (in Ukrainian).

Dergachov O., 1996. Ukrayins'ka derzhavnist' u XX stolitti (Istoryko-politolohichnyy analiz) (Ukrainian statehood in the 20th century (Historical and political analysis)). «Politychna dumka», Kyyiv (in Ukrainian).

Dergachov V.A., 2009. Geopoliticheskiy slovar'-spravochnik. (Geopolitical dictionary-reference book). Izdatel'stvo KNT, Kiyev (in Ukrainian).

Dergachov V.A., 2011. Geoekonomicheskaya transformatsiya Ukrainy. Monografiya (Geoeconomic transformation of Ukraine. Monograph) Elektronnoye izdaniye na CD. Izdatel'skiy proyekt professora Dergacheva. Online: http:/ / dergachev.ru/book-19/index.html (accessed: 12 April 2021).

Dnistryanskyj M.S., 2000. Ukrayina v polityko-heohrafichnomu vymiri (Ukraine in the political and geographical dimension). Vydavnychyy tsentr LNU imeni Ivana Franka, L'viv (in Ukrainian).

Dnistryanskyj M.S., 2007. Vvstup do istorychnoyi heohrafiyi Ukrayiny: tsykl lektsiy. (Introduction to the historical geography of Ukraine: A series of lectures). Vydavnychyy tsentr LNU im. I. Franka, L'viv (in Ukrainian).

Dnistryanskyj M.S., 2008. Etnoheohrafiya Ukrayiny: navchal'nyy posibnyk. (Ethnogeography of Ukraine: A textbook). Vydavnychyy tsentr LNU im. I. Franka, L'viv (in Ukrainian).

Dnistryanskyj M.S., 2010. Politychna heohrafich i heopolityka Ukrayiny (Political geography and geopolitics of Ukraine). Navchal'na knyha - Bohdan, Ternopil' (in Ukrainian).

Dnistryanskyj M.S., 2011. Heopolityka: navchal'nyy posibnyk (Geopolitics: A textbook). Vydavnychyy tsentr LNU im. I. Franka, L'viv. Online: http://old.geography.lnu. edu.ua/Strukt/Biblio/alphavit/Ukr/Ukr_D/Dnistrianskyi/geopolityka.pdf (accessed: 10 April 2021).

Doroshko M.S., Shpakova N.V., 2011. Heopolitychne seredovyshche ta heopolitychna oriyentatsiya krayin SND: navchal'nyy posibnyk (Geopolitical environment and geopolitical orientation of the CIS countries: A textbook). Tsentr uchbovoyi literatury, Kyyiv (in Ukrainian).

Dzhaman M.O., Shukanov P.V., 2007. Heopolitychni aspekty tsyvilizatsiynoho vyboru Ukrayiny (Geopolitical aspects of the civilisational choice of Ukraine) Naukovi zapysky Vinnyts'koho DPU im. M. Kotsyubyns'koho. Seriya «Heohrafiya» 13(1): 112-134 (in Ukrainian).
Dziuba I., 1990. Internatsionalizm chy rusyfikatsiya (Internationalism or Russification). Zhurnal «Vitchyzna» 5-7: 25-52 (in Ukrainian).

Galjchynskyj A.S., 2002. Ukrayina na perekhresti heopolitychnykh interesiv (Ukraine at the crossroads of geopolitical interests). Znannya Ukrayiny, Kyyiv (in Ukrainian).

Gvozdj V., 2020. Osoblyvosti rozvytku suchasnoyi heopolitychnoyi sytuatsiyi v sviti. Rol' Ukrayiny ta yiyi mistse u svitovykh i rehional'nykh protsesakh (Features of the current geopolitical situation in the world. The role of Ukraine and its place in global and regional processes). Nezalezhnyy analitychnyy tsentr heopolitychnykh doslidzhen'. Online: https://bintel.org.ua/nash_archiv/arxiv-geopolitika/osoblivosti_rozvitku/ (accessed: 12 April 2021) (in Ukrainian).

Gyorgy A., 2013. The application of German geopolitics: Geo-sciences. American Political Science Review 37(4): 677686. DOI $10.2307 / 1950008$.

Heopolitychnyy shchodennyk Viktora Hvozdya (Victor Gvozd's Geopolitical Diary). Online: https://bintel.org.ua/category/blog-hvozd/ (accessed: 8 April 2021) (in Ukrainian).

Heopolityka Ykrayiny: istoriya i suchasnist'. Naukovyy visnyk (Geopolitics of Ukraine: History and modernity. Scientific Bulletin). Online: http:/ / geopolitics-of-ukraine.uzhnu.edu.ua/ (accessed: 8 April 2021) (in Ukrainian).

Istorychna dovidka pro etapy ukrayins'koho derzhavotvorennya (Historical information about the stages of Ukrainian state formation). Online: http://burshtyn-rada.if.gov. ua/novyny/istorychna-dovidka-pro-etapy-ukrayinskogo-derzhavotvorennya/ (accessed: 13 April 2021) (in Ukrainian).

Kaminsky A., 2005. Na shlyakhu do natsional'noyi derzhavy (On the way to the nation state). Vydavnytstvo «Hadyach», Hadyach (in Ukrainian).

Kapustyan G., 2016. Ukrayins'ka derzhavnist': etapy stanovlennya (Ukrainian statehood: Stages of formation). Materialy III rehional'noyi naukovo-praktychnoyi konferentsiyi. Online: https://okrain.net.ua/uk/article/read/ Ukrainskaja-gosudarstvennost-etapy-stanovlenija.html (accessed: 15 April 2021) (in Ukrainian).

Klyuchko D., 2002. Heostratehichni vymiry natsional'noyi bezpeky ta instytuty yiyi zabezpechennya $\mathrm{v}$ Ukrayini (Geostrategic dimensions of national security and institutions of its provision in Ukraine). Visnyk Kharkivs'koho natsional'noho universytetu im. V.N.Karazina. Pytannya politolohiyi 555(2): 104-110 (in Ukrainian). DOI 10.15407/ socium2002.01.104.

Kolosov V.A., Mironenko N.S., 2005. Geopolitika i politicheskaya geografiya (Geopolitics and Political Geography). Aspekt Press, Moskva (in Russian).

Krushinsky V., Levenets A., 1993. Istoriya Ukrayiny. Podiyi ta fakty (History of Ukraine. Events and facts). Zodiak-EKO, Kyyiv (in Ukrainian).

Krypyakevych I., 1995. Ohlyad istoriyi Ukrayiny (Review of the history of Ukraine). Vyshcha shkola, Kyyiv (in Ukrainian).

Kubiyovych V., 1943. Heohrafiya ukrayins'kykh i sumizhnykh zemel' (Geography of Ukrainian and adjacent lands). Ukrayins'ke Vydavnytstvo, Krakiv-L'viv (in Ukrainian).

Kukhta B., 1994. Z istoriyi ukrayins'koyi politychnoyi dumky (From the history of Ukrainian political thought). Heneza, Kyyiv (in Ukrainian).

Larrabee F.S., 2010. Russia, Ukraine, and Central Europe: The return of geopolitics. Journal of International Affairs 
63(2): 33-52. Online: https://jia.sipa.columbia.edu/russia-ukraine-and-central-europe-return-geopolitics (accessed: 10 April 2021).

Lypa Y., 1942. Chornomrs'ka doktryna (Black Sea Doctrine). Ukrayins'kyy chornomors'kyy Instytut, Odesa. Online: https:/ / archive.org/ details/Chornomorska-doktryna--Lypa/page/5/mode/2up (accessed: 12 April 2021) (in Ukrainian).

Madison V.V., Shakhov V.A., 2003. Suchasna ukrayins'ka heopolityka: pidruchnyk dlya universytetiv (Contemporary Ukrainian geopolitics: A textbook for universities). Lybid', Kyyiv (in Ukrainian).

Martsikhiv K., Shepelyak L., 2020. Heopolitychni tsili ta heostratehiya Ukrayiny (Geopolitical goals and geostrategy of Ukraine). Visnyk Kharkivs'koho natsional'noho universytetu imeni V.N. Karazina. Seriya "Pytannya politolohiyi» 37(2): 116-124. DOI 10.26565/2220-8089-2020-37-15.

Minsterrstvo zakordonnykh sprav Ukrayiny (Ministry of Foreign Affairs of Ukraine). Online: https://mfa.gov.ua/ pitannya-mizhnarodnoyi-bezpeki (accessed: 12 April 2021) (in Ukrainian).

Panchenko M., 2019. Ukraine's place in the geopolitical puzzle is shifting. That was the point. Online: https://www.atlanticcouncil.org/blogs/ukrainealert/ukraines-place-inthe-geopolitical-puzzle-is-shifting-that-was-the-point/ (accessed: 5 April 2021) (in Ukrainian).

Pashchenko V.M., 2010. Metodolohiya ta metody naukovy$k h$ doslidzhen' (Methodology and methods of scientific research). Vydavnytstvo Aspekt-Polihraf, Nizhyn (in Ukrainian).

Suremain P.D., Verluise P., 2014. An interview with Philippe de Suremain, French Ambassador in Ukraine from 2002 to 2005. Online: https://www.diploweb.com/Geopolitics-of-Ukraine.html (accessed: 8 April 2021) (in Ukrainian).

Politolohichnyy slownyk (Political Science Dictionary). Online: https://subject.com.ua/political/zapit/index.html (accessed: 8 April 2021) (in Ukrainian).

Pyrozhkov S., 2000. Ukrayins'ki prioritety $\mathrm{v}$ heopolitytsi (Ukrainian priorities in geopolitics). Zhurnal «Viche» 5: 45-51 (in Ukrainian).

Shabliy O.I., 1993. Akademik Stepan Rudnyts'kyy - fundator ukrayins'koyi heohrafiyi (Academician Stepan Rudnytsky - the founder of Ukrainian geography) L'viv-Myunkhen, Redaktsiyno-vydavnychyy viddil L'vivs'koho derzhavnoho universytetu (in Ukrainian).

Shulga M.O., 2009. Heopolitychni oriyentatsiyi naselennya $i$ bezpeka Ukrayiny (za danymy sotsiolohiv) (Geopolitical orientations of the population and security of Ukraine (according to sociologists' data)). TOV «Drukarnya «Biznespolihraf», Kyyiv (in Ukrainian).

Skitsj I., 2015. Heohrafichnyy tsentr Yevropy-selo Dilove. Analitychne doslidzhennya (Geographical center of Europe-village Dilove. Analytical research). Online: https:/ / zaxid.net/geografichniy_tsentr_yevropi_selo_ dilove_n1374223 (accessed: 7 April 2021) (in Ukrainian).

Störk B., 2015. Geopolitical situation of Ukraine and its importance. Security and Defence 8(3): 17-39. DOI 10.5604/23008741.1189405.

Terranova G., 2020. Geopolitics of Covid-19: Global challenge at national borders. AIMS Geosciences 6(4): 515-524. DOI 10.3934/geosci.2020029.

Topchiyev O.H., 2005. Suspil'no-heohrafichni doslidzhennya: metodolohiya, metody, metodyky (Socio-geographical research: Methodology, methods, techniques). Astroprynt, Odessa (in Ukrainian).

Ukrayins'kyy tsentr ekonomichnykh i politychnykh doslidzhen' imeni Olesandra Razumkova (Olesandr Razumkov Ukrainian Center for Economic and Political Studies). Online: https:/ / razumkov.org.ua/images/Material_Conference/2021_03_18/18_03_2021_pids.pdf (accessed: 15 April 2021) (in Ukrainian).

Vasylenko S.D., 2000. Ukrayina: heopolitychni vymiry v zahal'no yevropeys'komu protsesi (Ukraine: Geopolitical dimensions in the general European process). Visnyk KHNU imeni V. N. Karazina. Seriya «Pytannya politolohiyi» 37(2): 116-124. Online: https://periodicals.karazin.ua/ politology/article/view/15974 (accessed: 15 April 2021) (in Ukrainian).

Yatsenko B.P., Stafiychuk V.I., Braichevsky Y.S., 2007. Politychna heohrafiya ta heopolityka (Political geography and geopolitics). Kyyiv: Lybid' (in Ukrainian).

Zhurnal "Natsional'na bezpeka i oborona" (National Security and Defense: Scientific Journal). Online: https://razumkov. org.ua/vydannia/zhurnal-natsionalna-bezpeka-i-oborona (accessed: 12 April 2021) (in Ukrainian).

Zinko I., 2012. Ukrayina u noviy heopolitychniy real'nosti: stratehichnyy poserednyk chy bufer? (Ukraine in the new geopolitical reality: A strategic mediator or a buffer?) Visnyk L'vivs'koho universytetu. Seriya «mizhnarodni vidnosyny» 30(2): 113-120 (in Ukrainian).

Zinyak L., 2014. Military cooperation between Ukraine and the European Union under the Association Agreement and an issue of state sovereignty. Security and Defence 2(1): 7-23. DOI 10.5604/23008741.1152784. 